\author{
B. Yilmaz', E. T. Irmak', Y. Turhan ${ }^{3}$, S. Doğan ${ }^{1}$, M. Doğan ${ }^{3 *}$ O. $\operatorname{Turhan}^{3}$ \\ Balikesir University Faculty of Science and Literature Department of Molecular Biology and \\ Genetics $^{1}$ and Chemistry, 10145 Çăğş-Balıkesir, Turkey \\ ${ }^{2}$ Hitit University Faculty of Engineering Department of Chemical Engineering 19030 Çorum, \\ Turkey \\ *mdogan@balikesir.edu.tr; mdogan7979@gmail.com
}

\title{
SYNTHESIS, CHARACTERIZATION AND BIOLOGICAL PROPERTIES OF INTERCALATED KAOLINITE NANOCLAYS: INTERCALATION AND BIOCOMPATIBILITY
}

\begin{abstract}
The aims of the present study were to synthesize the intercalated kaolinite samples with dimethylsulfoxide (DMSO), glutamic acid (GA), succinimide (SIM), cetylpyridiniumchloride (CPC), and hexadecyltrimethylammoniumchloride $\left(\mathrm{HDTMA}^{+}\right)$; to characterize by X-ray diffraction (XRD), BrunauerEmmett-Teller (BET), scanning electron microscopy (SEM), transmission electron microscopy (TEM), Fourier transform infrared spectroscopy-attenuated total reflectance (FTIR-ATR), and to determine the hemocompatibility and the cytotoxic effects of the intercalated kaolinite nanoclays on human lymphocytes. It was found that the intercalation with DMSO did not cause any decrease in cell viability until its maximum concentration $(500 \mu \mathrm{g} / \mathrm{mL})$, however, the intercalation with SIM, CPC, and (HDTMA ${ }^{+}$) causd important decreases in lymphocyte viabilities. It was determined that no significant decrease was observed in protein content of the lymphocyte cells exposed to the kaolinite nanoclays except the ones intercalated with SIM. Furthermore, the pristine kaolinite nanoclays which were intercalated with DMSO, GA, and SIM exhibited high hemocompatibility and the nanoclays intercalated with $\mathrm{CPC}$ and $\left(\mathrm{HDTMA}^{+}\right)$were highly hemocompatibile for the amounts below 125 and $500 \mu \mathrm{g} / \mathrm{mL}$, respectively. All the results of this work can serve for the human risk assesment of intercalated nanoclays.
\end{abstract}

Keywords: Intercalated kaolinite nanoclay; cytotoxicity; hemocompatibility

\section{INTRODUCTION}

Nanoclays that are naturally occurred layered silicates have been applied to fabricate biopolymers as nanocomposites for various biomedical applications due to its unique properties such as high ion exchange capacity, biocompatibility, ease of handling, and low cost [1]. Nanoclays enable the preparation of the novel biomaterials with improved structural and functional characteristics because they enhance the mechanical, chemical, physical, and thermal features of the polymer composites [2,3]. Kaolinite is one of the most abundant aluminosilicates consisting of tetrahedral $\mathrm{SiO}_{2}$ and octahedral $\mathrm{AlO}_{3}$ sheets in 1:1 arrangement. Kaolinite shows rapid adsorption kinetics for small molecules due to the strong hydrogen bonds between the hydroxyl of octahedral layer and the oxygen of tetrahedral layer [4-6]. Intercalation of the nanoclay via the immobilization of various molecules in the interlayer 
spaces causes to reduce the strength of the forces between these layers, thus, resulting in expansion of the basal spacing of the nanoparticles. The intercalation process alters the chemical structure of the nanoclay surface by changing surface chemistry and the morphological structure of the nanoclay by extending the basal space $[7,8]$. The intercalated nanoclays pave the way for the formation of novel polymer nanocomposites with the tunable changes on surface of nanoclays [9]. Because nanoclays have size in nanometer scale, they provide higher surface area available to contact with microenvironment, thus, it increases the risk of the possible toxicity. Although the technological characteristics of nanoclays are well described, the toxicological effects of the intercalated nanoclays still requires to be researched $[10,11]$. The aims of the present study were to prepare the intercalated kaolinite samples with dimethylsulfoxide (DMSO), glutamic acid (GA), succinimide (SIM), cetylpyridinium chloride (CPC), and hexadecyltrimethylammoniumchloride ( $\mathrm{HDTMA}^{+}$); to characterize by Xray diffraction (XRD), Brunauer-Emmett-Teller (BET), scanning electron microscopy (SEM), transmission electron microscopy (TEM), Fourier transform infrared spectroscopy-attenuated total reflectance (FTIR-ATR); and to determine the cytotoxic effects of the intercalated kaolinite nanoclays on human lymphocytes in order to asses human risk exposured to these nanoparticles. Human blood cells serve as good indicators of the state of the body in the case of exposure because they circulate through the body $[12,13]$. The human lymphocytes were selected to evaluate the cytotoxic effects of the intercalated nanoclays using MTS and Bradford assays as well as hemocompatibility test.

In the present work, intercalated kaolinite nanoclays (IKNC) were imaged under scanning electron microscopy to observe its distribution inside human lymphocytes. MTS assay for cytotoxicity analysis were performed to examine the cell viability of IKNCs. Total protein contents of the lymphocyte cells were exposed to different amounts of nanoclay samples. The nanoclays caused some decreases in total protein contents with their increasing amounts. The hemocompatibility of kaolinite nanoclays intercalated with various agents were investigated. All the results showed that unmodified, DMSO modified, GA modified and SIM, CPC and HDTMA $^{+}$intercalated kaolinite nanoclays could be classified as highly hemocompatible for all of the amounts used in this study. These results provide a more comprehensive evaluation of IKNCs and will be very well useful for its further application such as, clinical researchs, biomedical applications and various tissue engineering applications, particularly to bone defects.

\section{MATERIALS AND METHODS}

\section{Materials}

The chemicals were purchased from Sigma-Aldrich, Acros Organics (Kaolinite), GE Healthcare (Ficoll Paque), and Promega (CellTiter 96® AQueous One Solution Cell Proliferation Assay). In this study, all of the chemicals were analytical grade and used without further purification.

\section{Methods}

\section{Preperation of Intercalated Kaolinite Nanoclays}

The intercalation of kaolinite nanoclays with DMSO, GA, SIM, CPC, and HDTMA ${ }^{+}$ were performed by the method of Turhan et al. (2010) [14] and the codes of the samples were listed in Table 1. 
Table 1. Sample codes used in study

\begin{tabular}{ll}
\hline Code & Sample name \\
\hline$K_{0}$ & Kaolinite nanoclay \\
$K D$ & Kaolinite nanoclay intercalated with DMSO \\
$K D-G A$ & Kaolinite nanoclay intercalated with GA \\
$K D-S I M$ & Kaolinite nanoclay intercalated with SIM \\
$K D-C P C$ & Kaolinite nanoclay intercalated with CPC \\
$K D-H D T M A^{+}$ & Kaolinite nanoclay intercalated with $\mathrm{HDTMA}^{+}$ \\
\hline
\end{tabular}

For the DMSO modification, the sieved kaolinite nanoclay $\left(\mathrm{K}_{0}\right)$ and DMSO were mixed and placed into an ultrasonic bath for $20 \mathrm{~min}$. After stirring at $80^{\circ} \mathrm{C}$ for $120 \mathrm{~h}$, it was filtered and washed with methanol. This sample was called as KD. $2 \mathrm{~g}$ of GA, $2 \mathrm{~mL}$ of HCl, and $2 \mathrm{~g}$ of $\mathrm{KD}$ sample were mixed in $200 \mathrm{~mL}$ of the distilled $\mathrm{H}_{2} \mathrm{O}$ at $80^{\circ} \mathrm{C}$ for $\mathrm{GA}$ modification (KDGA). After the filtration step, the product was washed with hot water and, then, dried. Another modification was done by the displacement of DMSO with SIM (KD-SIM). In order to do this, $1 \mathrm{~g}$ of KD and $0.1 \mathrm{~g} / \mathrm{mL}$ of SIM were stirred for $120 \mathrm{~h}$ at room temperature, filtered under vacuum, washed with 2-propanol, and dried in air. For the modification with CPC (KD$\mathrm{CPC}$ ), $2 \mathrm{~g}$ of $\mathrm{KD}$ sample, $100 \mathrm{~mL}$ of the distilled $\mathrm{H}_{2} \mathrm{O}$, and $0.78 \mathrm{~g}$ of CPC were stirred for $8 \mathrm{~h}$. The suspension was then centrifuged for $5 \mathrm{~min}$ at $3000 \mathrm{rpm}$ and pellet was filtered, washed, and, then, dried at $80{ }^{\circ} \mathrm{C}$. The last modification was performed with $\mathrm{HDTMA}^{+}$(KD$\left.\mathrm{HDTMA}^{+}\right) .2 \mathrm{~g}$ of $\mathrm{KD}, 100 \mathrm{~mL}$ of $\mathrm{HDTMA}^{+}(2 \mathrm{mmol})$, and $100 \mathrm{~mL}$ of distilled $\mathrm{H}_{2} \mathrm{O}$ were stirred under reflux at $80{ }^{\circ} \mathrm{C}$ for $24 \mathrm{~h}$. After it was centrifuged for $5 \mathrm{~min}$ at $3000 \mathrm{rpm}$, the pellet was filtered and washed. All the intercalation steps were demonstrated in Figure 1. The UV sterilized intercalated kaolinite nanoclays were interacted with a serum free medium (RPMI-1640) for $48 \mathrm{~h}$ in an ultrasonic bath at $37^{\circ} \mathrm{C}$. The serial half dilutions were prepared from the stock solutions $(1 \mathrm{mg} / \mathrm{mL})$ and the working amounts were used in the range of 3.91$500 \mu \mathrm{g} / \mathrm{mL}$.

Characterization of Intercalated Nanoclays

Surface Area Analysis (BET)

The surface areas of the kaolinite nanoclays were measured with BET (NOVA 2200e, Quantachrome Instruments). The nanoclays were degassed at $200^{\circ} \mathrm{C}$ for $24 \mathrm{~h}$.

XRD Analysis

The XRD measurements were performed with X-Ray diffractometer (Analytical Philips $X^{\prime}$ Pert-Pro) at room temperature. The analysis were carried out in the range of $5-50^{\circ}$ at a scanning rate of $2^{\circ} / \mathrm{min}$ at $30 \mathrm{~mA}$ and $40 \mathrm{kV}$ with $\mathrm{Cu} \mathrm{K \alpha}$ radiation of wavelength of $1.54 \mathrm{~nm}$.

FTIR-ATR Analysis

The FTIR-ATR spectrum of the samples were performed in the Attenuated Total Reflectance (ATR) mode using Perkin Elmer Spectrum 100. The samples were scanned from 4000 to $650 \mathrm{~cm}^{-1}$.

\section{Scanning Electron Microscope (SEM) Analysis}

The measurements were performed with scanning electron microscope (FEI Quanta 200 FEG). One drop of $1 \mathrm{~mm}^{2}$ sample/1 mL solvent was put onto wafer. The samples were put in 
the incubator for $2 \mathrm{~h}$ to remove the solvent. The working parameters were shown on the SEM micrographs.

\section{High Resolution Transmission Electron Microscope (HRTEM) Analysis}

TEM measurements of all the kaolinite nanoclays were performed using high resolution transmission electron microscope (FEI Tecnai G2 F30). After the suspensions were dispersed under ultrasonic bath for $10 \mathrm{~min}$, the samples were droped at copper grits coated with carbon. The samples were dried and analysed below $200 \mathrm{kV}$ taking at least four images.

\section{Lymphocyte Isolation}

Ficoll-Paque reagent was used for lymphocyte isolation from the heparinized fresh blood samples, which were taken from healthy and non-smoking human donors. Isolated lymphocytes were dissolved in $5 \mathrm{~mL}$ of RPMI 1640 medium containing $10 \%$ FBS, 1\% PenStrep, and $0.1 \mathrm{~g} / \mathrm{L}$ of phytohaemagglutinin $\left(2 \times 10^{6}\right.$ cells $\left./ \mathrm{mL}\right)[15,16]$.

\section{Cytotoxicity Assay}

MTS assay for cytotoxicity analysis was performed according to the method of Maisanaba et al. (2014) with some modifications [17]. For this test, nanoclays treated mediums were added into the cell cultures after $24 \mathrm{~h}$ of incubation of isolated lymphocytes. Then, the samples were incubated for $48 \mathrm{~h}$ at $37^{\circ} \mathrm{C}\left(5 \% \mathrm{CO}_{2}\right)$. The negative control group was prepared without nanoclay sample. At the end of each 24 hour, $100 \mu \mathrm{L}$ of cells were treated with $20 \mu \mathrm{L}$ of MTS reagent. Cell viabilities were analyzed measuring the absorbances at 490 $\mathrm{nm}$, after 4 hours of incubation at $37^{\circ} \mathrm{C}[18]$.

\section{Bradford Method}

The total protein contents of the lymphocyte cultures treated with nanoclays and control groups were determined by Bradford method after each incubation period $[19,20]$. The lymphocyte cultures were centrifuged at $1500 \mathrm{rpm}$ for $10 \mathrm{~min}$ and the supernatants were discarded. $200 \mu \mathrm{L}$ of $\mathrm{NaOH}(0.1 \mathrm{M})$ was added into the lymphocyte pellet and incubated for 2 $\mathrm{h}$ at $37^{\circ} \mathrm{C}$. After second centrifugation, the pellets were treated with $200 \mu \mathrm{L}$ of CoomassieBlue G-250 reagent prepared by dissolving $100 \mathrm{mg}$ of reagent in $1000 \mathrm{~mL}$ of the distilled $\mathrm{H}_{2} \mathrm{O}$ having $5 \%(\mathrm{v} / \mathrm{v})$ of ethanol and $10 \%(\mathrm{v} / \mathrm{v})$ of phosphoric acid. In order to get a calibration curve, different concentrations of bovine serum albumin $(0.1-1 \mathrm{mg} / \mathrm{mL})$ were used. The protein contents of the samples were determined spectrophotometrically at $595 \mathrm{~nm}$ with a microplate reader.

\section{Hemocompatibility Assay}

The hemocompatibility properties of the nanoclays were tested according to the method of Motlagh et al. (2007). Different amounts of the nanoclays were prepared with anticoagulated blood $(1: 50, \mathrm{v} / \mathrm{v})$ in $0.9 \% \mathrm{NaCl}$ solution. Negative control was prepared by using diluted blood without any nanoclay addition and positive control was prepared with ultrapure water $(1: 50, \mathrm{v} / \mathrm{v})$. Samples and control groups were incubated at $37^{\circ} \mathrm{C}$ for $2 \mathrm{~h}$ and centrifuged at $1000 \mathrm{~g}$ for $10 \mathrm{~min}$. The absorbances of the supernatants were measured at 545 $\mathrm{nm}$. The hemolysis \% was determined with the following equation [21]:

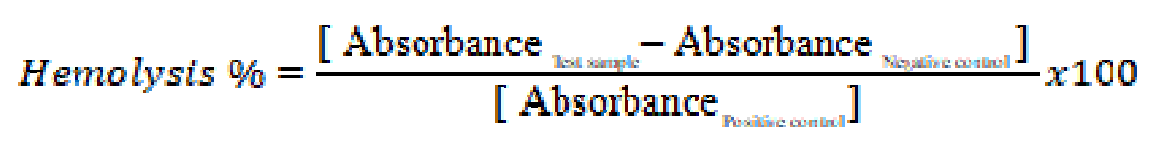




\section{Statistical Analyses}

Statistical analyses were performed by SPSS Statistics 22 Programme and the experiments were designed as three replicates. The significance of differences between the samples and the control groups was determined by one-way ANOVA test. Tukey and Tamhane's T2 tests were used for variance analyses. The results were considered as statistically significant when $p<0.05 . \mathrm{EC}_{50}$ values were calculated by linear regression analysis from the concentration-response graphs.

\section{RESULTS AND DISCUSSION}

\section{Characterization of Intercalated Nanoclays}

Van der Waals bonds between the Al-OH and Si-O groups in the clay layers make the clay intercalation process difficult. To overcome this difficulty, intercalation compounds are placed in the spaces between the clay layers, thus, the electrostatic attraction forces between the layers are reduced, the dielectric constant and polarity are increased. The crystalline structure of kaolinite modified with modifiers such as DMSO, GA, SIM, CPC, and HDTMA ${ }^{+}$ was presented in Figure 1. The species of guest molecules that enter between the layers of kaolinite are determined by the hydrogen bonds between the octahedral and tetrahedral layers of kaolinite, therefore, a limited number of polar molecules are used to locate kaolinite clay layers in the literature. One of these molecules is DMSO, which is a polar compound [22]. For this reason, modification and intercalation processes were carried out on DMSO-spaced kaolinite. The kaolinite nanoclays prepared in this work were characterized using various techniques such as BET, XRD, FTIR-ATR, SEM and TEM measurements.

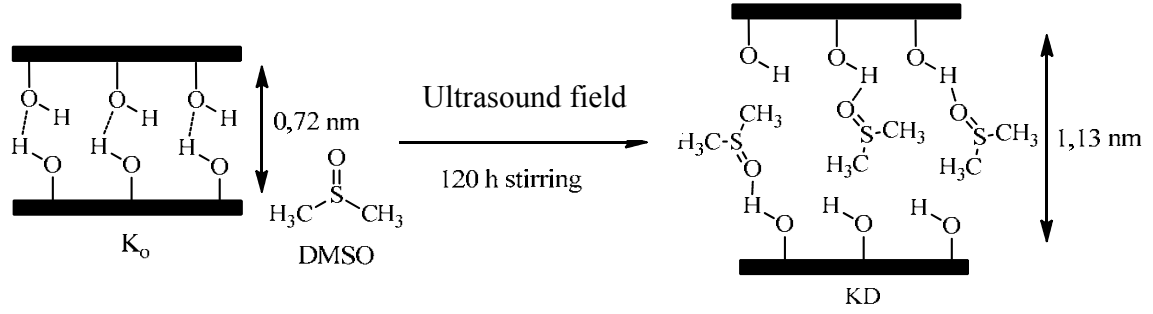

(a)

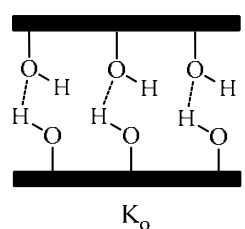<smiles>CCOC(=O)C(N)CCC(=O)O</smiles>

Glutamic acid

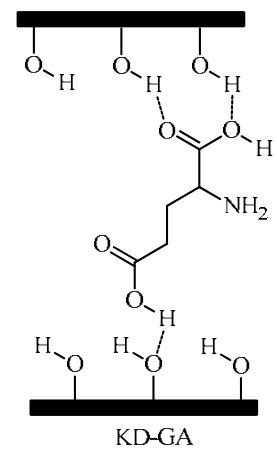


(b)

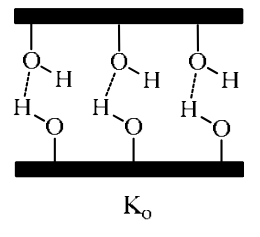

$\mathrm{K}_{\mathrm{o}}$

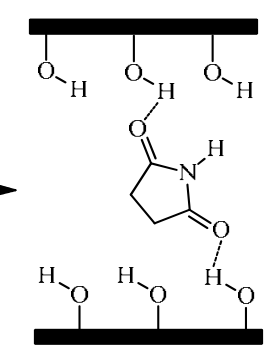

KD-SIM

(c)

$-\mathrm{OH}$
$-\mathrm{OH}$
$-\mathrm{OH}$

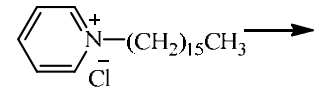

cetylpyridinium chloride

Cetylpyridinium chloride

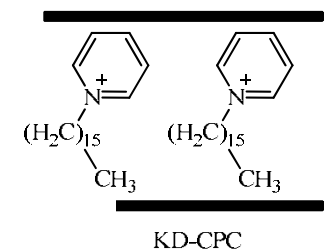

(d)

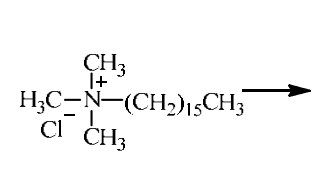

Hexadecyl trimethyl ammonium chloride

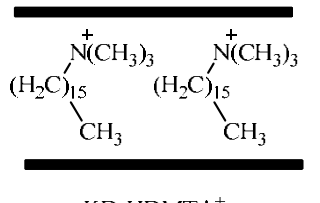

KD-HDMTA ${ }^{+}$

(e)

Fig. 1. The intercalation of kaolinite nanoclay with DMSO (a), GA (b), SIM (c), CPC(d) and $\operatorname{HDTMA}^{+}(e)$

Table 2. The BET surface area measurements of pristine and the intercalated kaolinite nanoclays

\begin{tabular}{cc}
\hline Nanoclays & Surface area $\left(\mathrm{m}^{2} / \mathrm{g}\right)$ \\
\hline Kaolinite & 8.81 \\
Kaolinite-DMSO (KD) & 21.69 \\
KD-SIM & 25.55 \\
KD-GA & 28.74 \\
KD-CPC & 34.43 \\
KD-HDTMA $^{+}$ & 34.44 \\
\hline
\end{tabular}

\section{BET Analysis}

The BET surface area measurements of all the kaolinite nanoclays were given in Table 2. The surface areas of the intercalated kaolinites were about 3-4 times higher than the surface area of pristine kaolinite, indicating that the intercalation caused the important changes in the structure of kaolinite. 


\section{XRD analysis}

The XRD patterns of intercalation of kaolinite with DMSO and other intercalated compounds were shown in Figure 2. The characteristic XRD peaks of kaolinite were disappeared at 7.162, 4.350, and 3.579 A. Kaolinite was intercalated with firstly DMSO and then with GA. Amino acids are molecules that include both amine and carboxyl groups. Patakfalvi and Dekany (2004) reported that the distance between 001 planes of kaolinite was increased from $0.72 \mathrm{~nm}$ to $1.12 \mathrm{~nm}$ after the intercalation with DMSO.

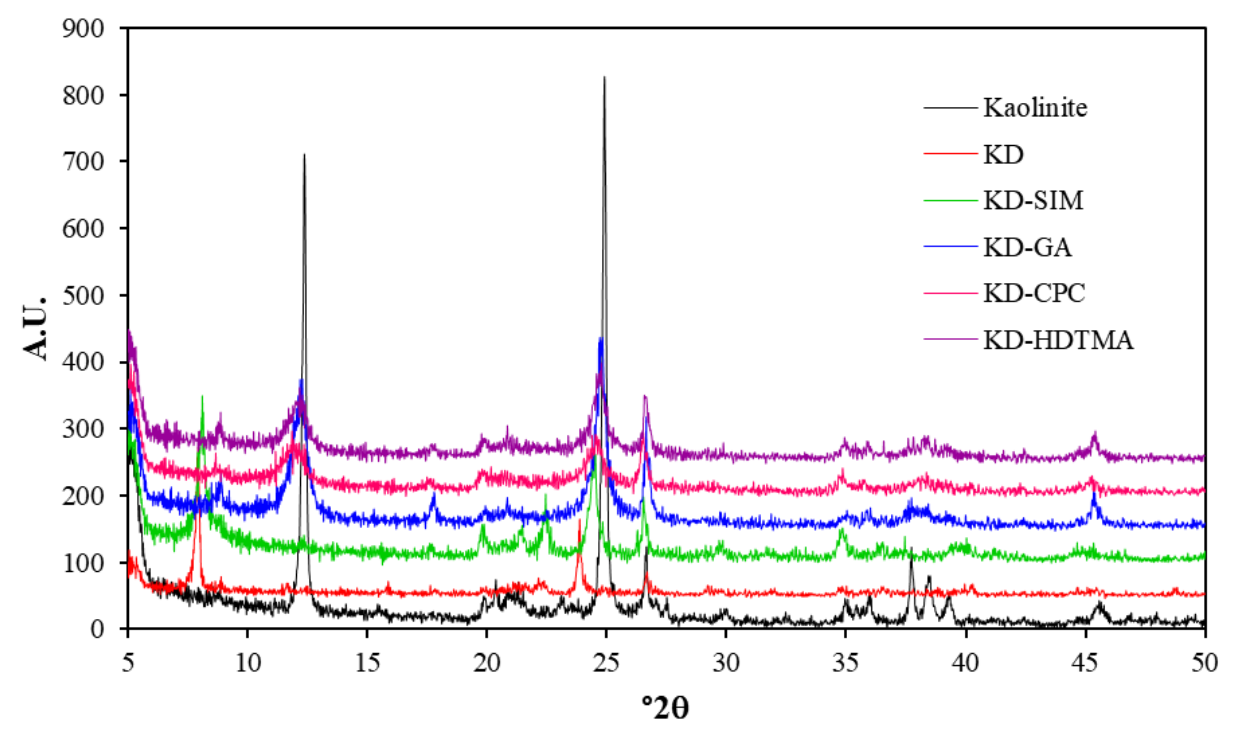

Fig. 2. XRD patterns of kaolinite and the intercalated kaolinite samples

In this study, the interspace between planes was increased from $0.712 \mathrm{~nm}$ to $1.113 \mathrm{~nm}$ after intercalation with DMSO. As seen from these XRD patterns, the modifiers replaced the place of DMSO at the end of replacement reaction of kaolinite nanoclay intercalated with DMSO and hydrogen bonds existed between kaolinite nanoclay and the modifiers. The new peaks at 25.545, 23.198, and $20.790 \AA$ were appeared at the end of substitution reaction and the peak of kaolinite-DMSO, which exists at $11.232 \AA$, was disappeared as the result of the substitution of GA with DMSO [23]. Elbokl and Detellier (2008) studied the intercalation reaction of cyclic imides with kaolinite and they reacted SIM and GA with kaolinite intercalated with DMSO. SIM and GA replaced with DMSO that was located between the planes of the kaolinite. Also, the interspace of kaolinite between 001 planes was increased from $7.2 \AA$ to $11.2 \AA, 12 \AA$, and $12.3 \AA$ with DMSO, SIM and GA, respectively [24]. In this study, the interspace was increased to $10.88 \AA$ at the end of the substitution reaction of KD with SIM. The significant decrease was occured in the peak intensity of kaolinite and KD$\mathrm{CPC}$ in Figure 2. The peak intensity of KD-CPC decreased to 100 because peak intensity of pristine kaolinite was 800 . Also, the peak of kaolinite 002 plane was shifted to left. The XRD pattern of $\mathrm{KD}$ intercalated with $\mathrm{HDTMA}^{+}$showed that the peak of $\mathrm{KD}$ was almost disappeared and the peak intensity of kaolinite at 002 plane was decresaed and shifted to left. Turhan et al. (2010) reported that the XRD patterns of the pristine kaolinite and its intercalated compounds such as KDMSO and SIM-KDMSO had characteristic peaks at $2 \theta=12.41^{\circ}, 2 \theta=7.93^{\circ}$, and $2 \theta=8.82^{\circ}$, respectively. This showed that the basal spacing ( $\left.d 001\right)$ of kaolinite shifted from 0.712 to $1.113 \mathrm{~nm}$, with KDMSO expanding which was an increase of $0.401 \mathrm{~nm}[14]$. 


\section{FTIR-ATR analysis}

In the kaolinite structure, there are three types of hydroxyl groups, namely inner surface hydroxyl, internal hydroxyl, and adsorbed water hydroxyl. FTIR-ATR spectrum of kaolinite was shown in Figure 3. The vibrations at 3687 and $3619 \mathrm{~cm}^{-1}$ are attributed to inner surface hydroxyl and internal hydroxyl groups, respectively (Figure 3a).

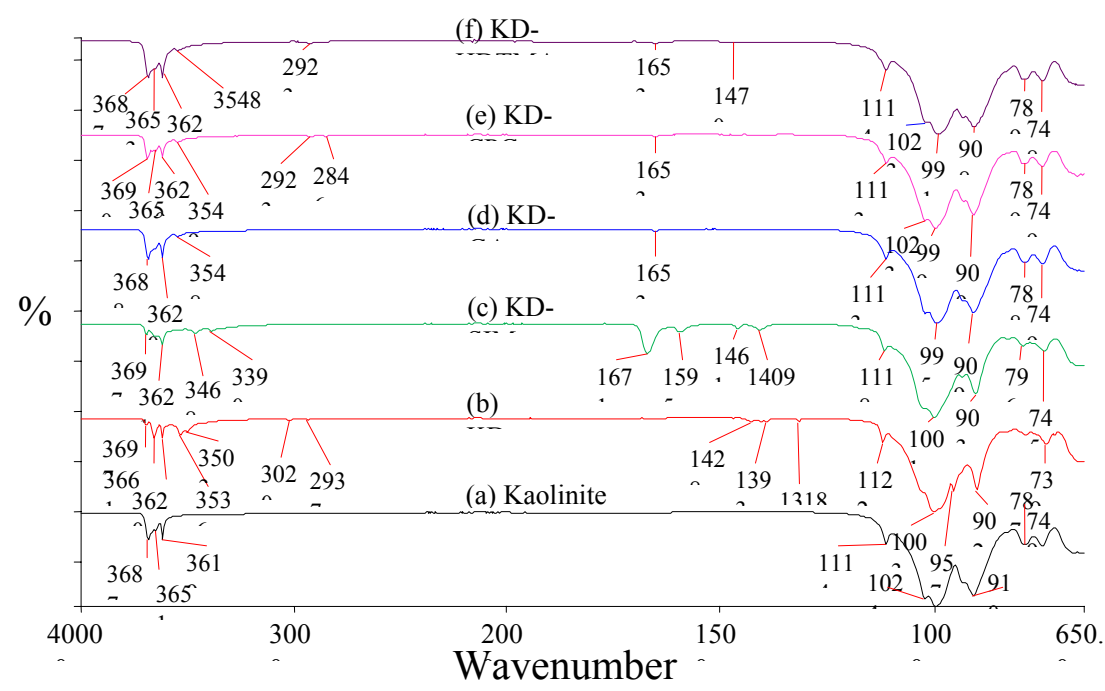

Fig. 3. FTIR-ATR spectra of kaolinite and the intercalated kaolinite samples

The vibration at $3651 \mathrm{~cm}^{-1}$ belongs to the adsorbated water. The vibrations at $3619 \mathrm{~cm}^{-1}$ belonging to the internal hydroxyl group are not affected by the modification reactions. On the contrary, the inner-surface hydroxyl strecthing bands are affected by the modification reactions. Other characteristic bands of kaolinite are $\mathrm{Si}-\mathrm{O}$ vibration bands at 1114, 1024, and $910 \mathrm{~cm}^{-1}$ and O-Al-OH vibration bands at 787 and $749 \mathrm{~cm}^{-1}$. Because of the hydrogen bonds between the plates, the layers can be directly intercalated with only a limited number of polar molecules such as N-methylformamide and DMSO. The intercalation reactions can be carried out by the spaced kaolinite with polar molecules to substitution reactions with new guest molecules. After the intercalation of kaolinite with DMSO, new vibrations were appeared at 3536 and $3503 \mathrm{~cm}^{-1}$, but the vibration at $3620 \mathrm{~cm}^{-1}$ was not affected (Figure $3 \mathrm{~b}$ ). The vibrations at 3687 and $3651 \mathrm{~cm}^{-1}$ were shifted to 3697 and $3661 \mathrm{~cm}^{-1}$, respectively. The band at $3661 \mathrm{~cm}^{-1}$ due to stretching vibration of the inner-surface hydroxyl group formed the hydrogen bond with $\mathrm{S}=\mathrm{O}$ group of DMSO. FTIR-ATR spectrum of KD-SIM was demonstrated in Figure 3c. In FTIR-ATR spectrum of KD-SIM, new vibration bands of hydrogen bonds at 3468 and $3390 \mathrm{~cm}^{-1}$ were found and the vibration originating from internal hydroxyl groups at $3620 \mathrm{~cm}^{-1}$ was unchanged. In addition, the vibrations at $1671,1595,1461$ and $1409 \mathrm{~cm}^{-1}$ were also derived from SIM, indicating that it entered the layers of kaolinite after the modification. Comparing the FTIR-ATR spectra the vibration at $3620 \mathrm{~cm}^{-1}$ remained unchanged and at $1653 \mathrm{~cm}^{-1}$ a new vibration originating from GA appeared. Low energy bands were also not observed due to the hydrogen of the guest molecules bound to the hydroxyl groups between the layers [24]. FTIR-ATR spectrum of KD-CPC was presented in Figure $3 \mathrm{e}$. When the spectrum was analyzed, it could be said that the peaks originating from the asymmetric/symmetric strecthing vibrations of the methylene groups of CPC at 2846 and $2923 \mathrm{~cm}^{-1}$ and the characteristic peaks of kaolinite at 3620 and $1113 \mathrm{~cm}^{-1}$ were observed. FTIR-ATR spectrum of KD-HDTMA ${ }^{+}$was shown in Figure 3f. The bands at 2921 and 2851 $\mathrm{cm}^{-1}$ in the spectrum resulted from the asymmetric and symmetric stretching of the aliphatic hydrocarbons chain of the hexadecyl group. In a work made by Lakshmi et al. (2008), peak of 
shear and bending bands of methylene groups of $\mathrm{HDTMA}^{+}$was recorded at $1472 \mathrm{~cm}^{-1}$. In this study, this vibration was around $1470 \mathrm{~cm}^{-1}$ due to the interaction of $\mathrm{HDTMA}^{+}$with kaolinite [25].

\section{SEM Analysis}

The SEM images of pristine kaolinite nanoclay and kaolinite intercalated with DMSO were shown in Figure $4 \mathrm{a}$ and $\mathrm{b}$. The working parameters were all existed on the photographs. All the results clearly demonstrated the layered structure of kaolinite nanoclays.
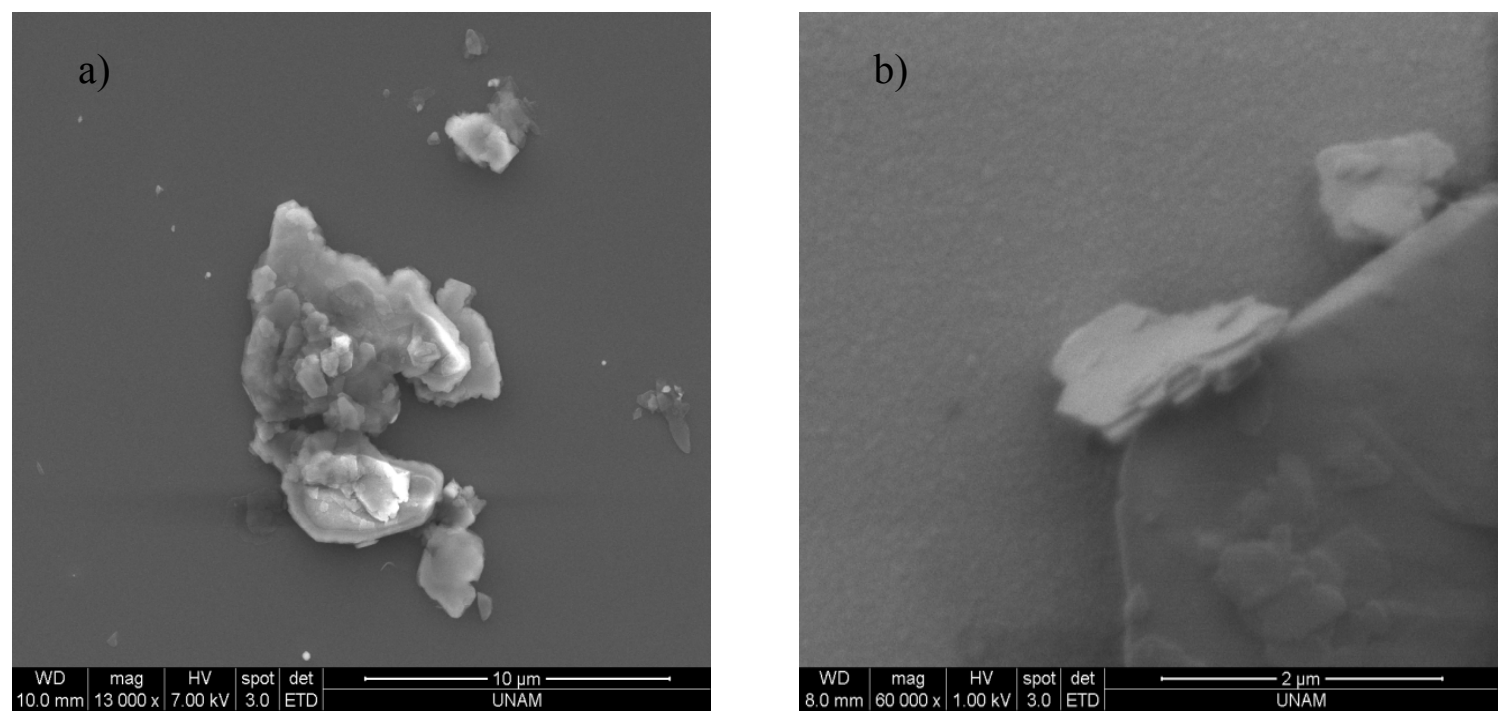

Fig. 4. SEM photographs of pristine kaolinite(a) and the intercalated kaolinite $K D(b)$ nano clays

\section{TEM Analysis}

TEM micrographs of pristine kaolinite nanoclays and KD were shown in Figure 5a and $b$. It was observed that the hexagonal structure of kaolinite crystals was changed to bar structures. Also, the decrease of size of the kaolinite particles and delamination of kaolinite boolets indicated that the intercalation was achieved. The dark regions at the TEM images occured due to the overlapping clay mass.

a)

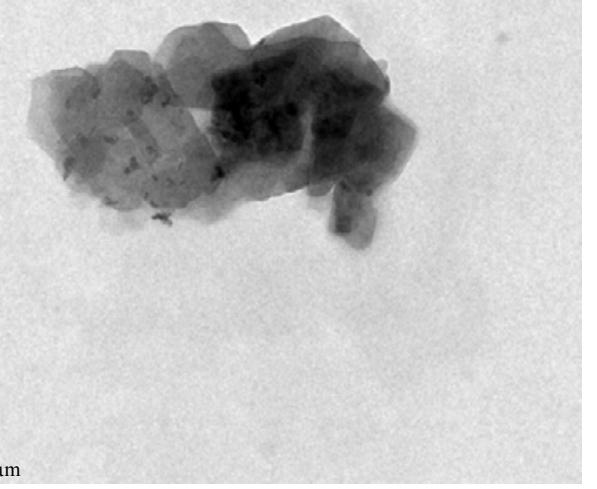

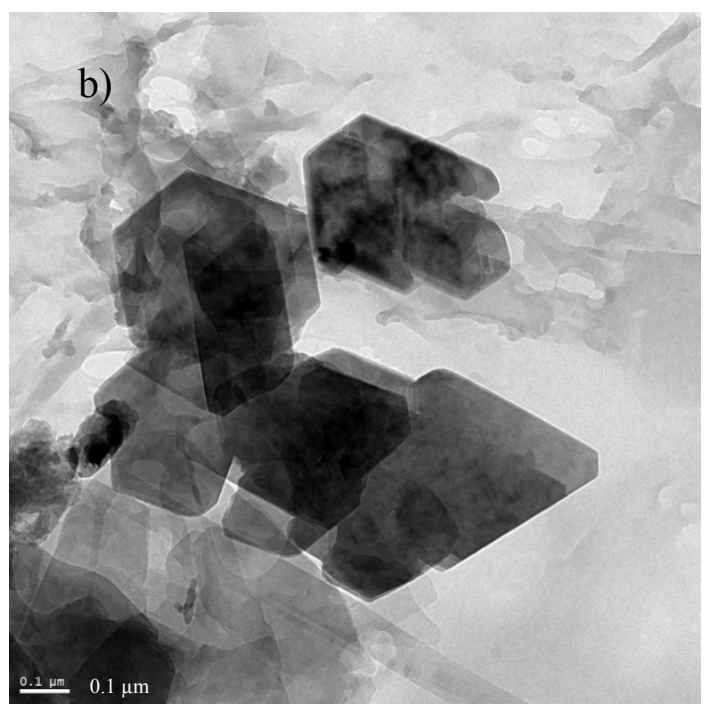

Fig. 5.TEM photographs of pristine kaolinite(a) and the intercalated kaolinite KD (b) nano clays 


\section{Cytotoxicity and Hemocompatibility Tests}

The intercalated nanoclays prepared in this work were aimed for the utilization in various biomedical applications such as drug delivery, wound dressing, hemostatic bandage, tissue engineering, bone cement etc therefore, it was necessary to test toxicity of the kaolinite samples on blood cells [5,8]. In this study, it was investigated the cytotoxicities of different kaolinite samples on healthy human lymphocytes using MTS and Bradford assays. In addition, hemocompatibility test was performed to detect if there was a release of hemoglobin into plasma because of the possible interactions between kaolinite and blood.

\section{MTS Assay}

The results of MTS assay for the human lymphocytes treated with the kaolinite nanoclay samples were shown in Figure 6. Intercalation of kaolinite with DMSO is commonly used as a first step of other modifications because disaggregation of the lamellae of the nonswelling kaolinite could be achieved by this way [25]. In this study, kaolinite nanoclay modified with DMSO (KD) didn't show significant change in cell viability until its maximum amount (500 $\mu \mathrm{g} / \mathrm{mL}$ ), thus, KD and KD-GA had less cytotoxic effect than kaolinite. Because the intercalation process altered the surface characteristics of the nanoclay such as hydrophilicity, ionic charge etc., the cytotoxicity behavior might be changed on this basis. According to the cytotoxicity results of the KD-GA, KD-SIM, KD-CPC, and KD-HDTMA ${ }^{+}$, it was clear that lymphocytes showed different reactions to intercalated kaolinite nanoclays modified with GA, SIM, CPC, and HDTMA ${ }^{+}$, respectively. Among all of the modifications, GA was the the best intercalation reagent for the kaolinite samples because the viabilities didn't decrease significantly with GA modified kaolinite samples for $24 \mathrm{~h}$ but only decreased at $500 \mu \mathrm{g} / \mathrm{mL}$ for $48 \mathrm{~h}$.

On the other hand, the intercalation with SIM, CPC, and $\mathrm{HDTMA}^{+}$caused important decreases in lymphocyte viabilities. When the MTS results of KD-SIM samples were examined, significant reductions in cell viabilities were observed for the amounts of 7.81 $\mu \mathrm{g} / \mathrm{mL}$ after $24 \mathrm{~h}$ and $48 \mathrm{~h}$ of incubations $(\mathrm{p}<0.05)$. Similarly, significant decreases of cell viabilities were seen with KD-CPC samples for the amounts of $15.62 \mu \mathrm{g} / \mathrm{mL}$ after $48 \mathrm{~h}$ $(\mathrm{p}<0.05)$. The cell viabilities were also significantly decreased with $3.91,15.62,31.25$, and $500 \mu \mathrm{g} / \mathrm{mL}$ of KD-CPC samples after $24 \mathrm{~h}$ of exposure $(\mathrm{p}<0.05)$. In addition, KD-HDTMA ${ }^{+}$ samples showed significant decreases with 15.62, 62.5, 125, 250, and $500 \mu \mathrm{g} / \mathrm{mL}$ for $24 \mathrm{~h}$ and $62.5,250$, and $500 \mu \mathrm{g} / \mathrm{mL}$ for $48 \mathrm{~h}(\mathrm{p}<0.05)$. When the $\mathrm{EC}_{50}$ values of all samples were compared, KD had the highest value for both of the incubation periods $(53.74 \mu \mathrm{g} / \mathrm{mL}$ for $24 \mathrm{~h}$ and $53.54 \mu \mathrm{g} / \mathrm{mL}$ for $48 \mathrm{~h}$ ). On the other hand, the least $\mathrm{EC}_{50}$ value was determined with $\mathrm{KD}$ CPC for $24 \mathrm{~h}(10.76 \mu \mathrm{g} / \mathrm{mL})$ and KD-HDTMA ${ }^{+}$for $48 \mathrm{~h}(8.07 \mu \mathrm{g} / \mathrm{mL})$.

In literature there are some predictions explaining the possible reasons of clay toxicities such as their low ion exchange capacities [26], bigger surface area [33], unique charge and hydrogen bonding properties which can cause a lysis of the cell membrane [34] and capacity to cause an oxidative stress $[10,17]$. It is well known that different modifiers have different effects on clay samples [11]. Also some studies existed in literature showing the effects of modifications that can change the cell responses. For example, Tiburu et al. (2016) investigated the effects of the zeolite A, which was synthesized at two different temperatures $\left(60^{\circ} \mathrm{C}\right.$ and $\left.105^{\circ} \mathrm{C}\right)$ from kaolin (LTA60 and LTA 105 , respectively) on HeLa cancer cell growth. The results showed that cytotoxic effect of LTA60 on the cancer cells was higher than LTA105 (60 $\pm 5,41 \pm 2$, and $70 \pm 4 \%$ for 24,48 , and $72 \mathrm{~h}$, respectively). The researchers suggested that this effect was seen due to the bigger surface area of this material compared to the LTA105 [35]. 
a)

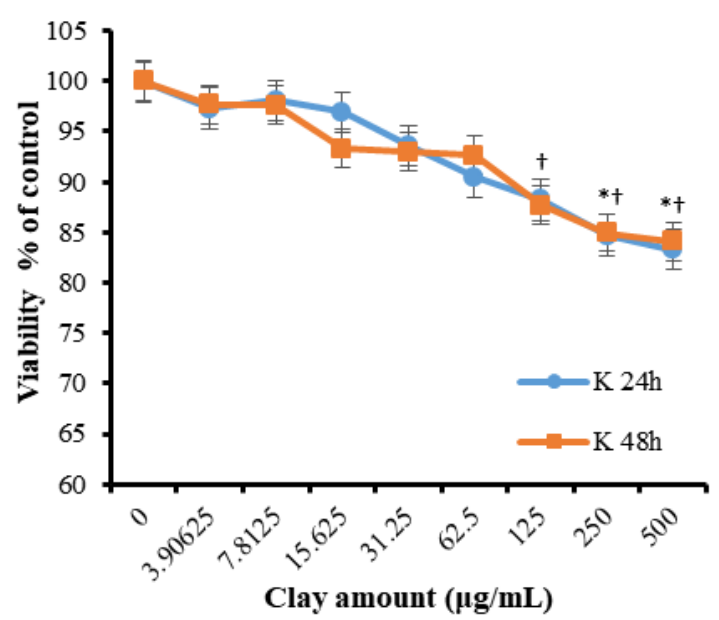

c)

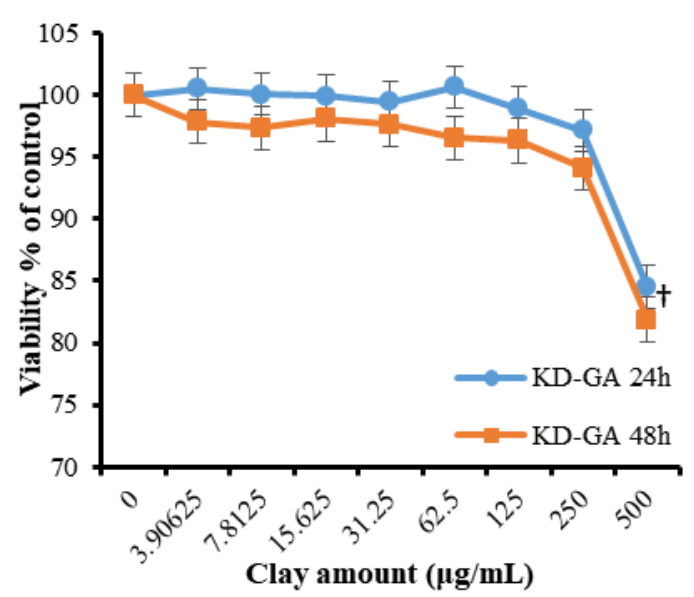

e)

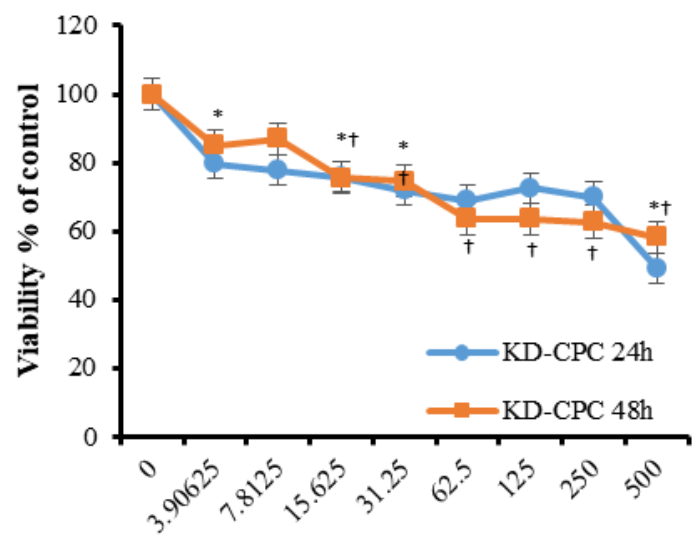

Clay amount $(\mu \mathrm{g} / \mathrm{mL})$ b)

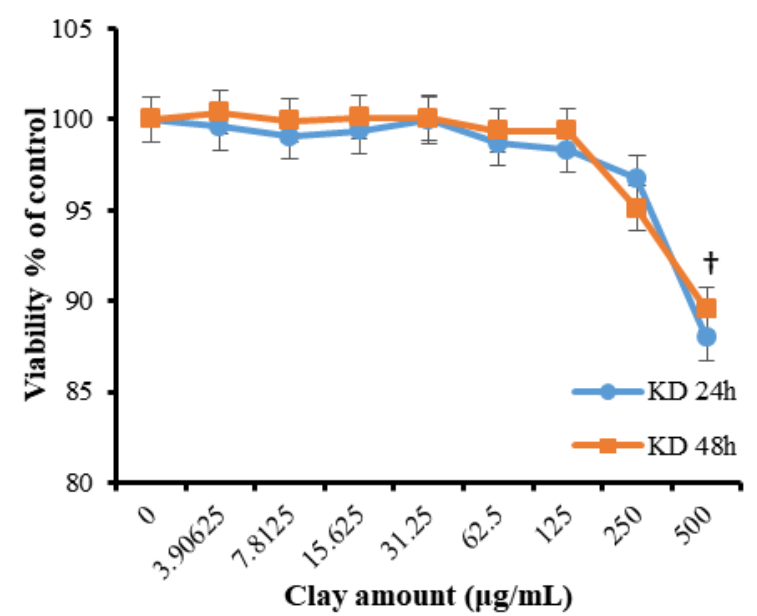

d)

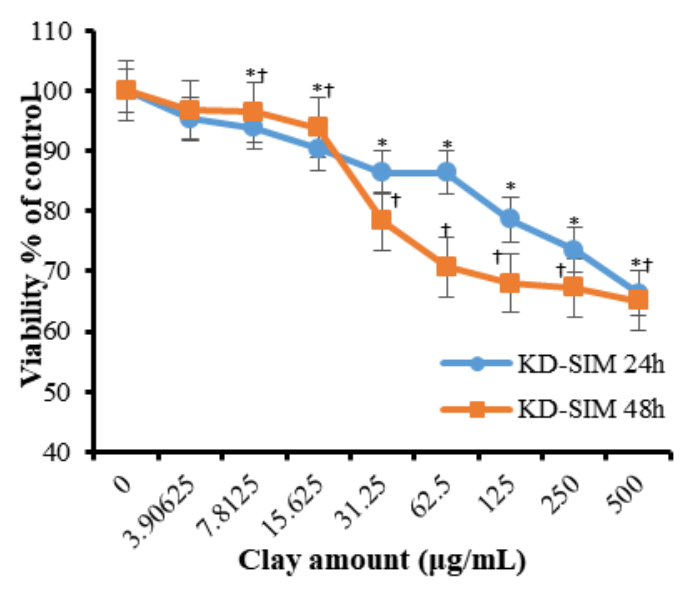

f)

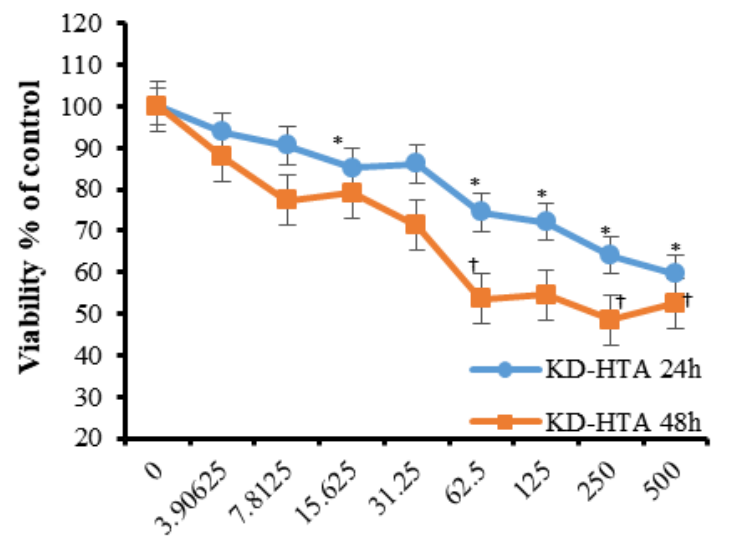

Clay amount $(\mu \mathrm{g} / \mathrm{mL})$

Fig. 6. MTS assay results of the human lymphocytes treated with different amounts of K0 (a); KD (b); KD-GA (c); KD-SIM (d); KD-CPC (e) and KD-HDTMA+ (f). Significance $(p<0.05)$ compared to negative control for $24 \mathrm{~h}$ shown as *, and for $48 \mathrm{~h}$ shown as $\dagger$. 
Maisanaba et al. (2014) also studied the cytotoxic effects of the unmodified nanoclay Cloisite ${ }^{\circledR} \mathrm{Na}^{+}$and the organically modified Cloisite ${ }^{\circledR} 30 \mathrm{~B}$ with Caco- 2 cells after 24 and $48 \mathrm{~h}$ of incubations. The researchers examined total protein content, neutral red uptake and a tetrazolium salt reduction and found that only modified one (Cloisite ${ }^{\circledR}$ 30B) induced toxic effects. The cells showed significant decreases with $62.50 \mu \mathrm{g} / \mathrm{mL}$ and $3.91 \mu \mathrm{g} / \mathrm{mL}$ of modified clay after 24 and 48 hours of incubations, respectively [17]. In another study of Maisanaba et al. (2017), cytotoxic effects in human cell lines exposed to two different silane modified clay minerals were evaluated. No cytotoxic damage was observed as a result of the 3aminopropyltriethoxysilane modified clay exposure but an important decrease in cell viability was occured with the vinyltrimethoxysilane modified clays [36].

\section{Bradford Assay}

Total protein content of the cells is known to be used as another parameter for cytotoxicity analyses [17,20]. Total protein contents of the lymphocyte cells exposed to different amounts of nanoclay samples were shown in Figure 7. The results showed that there wasn't any significant decrease in the total protein content of the lymphocyte cells exposed to the kaolinite nanoclays except only the nanoclays intercalated with SIM. The total protein content of the cells incubated with KD-SIM $(500 \mu \mathrm{g} / \mathrm{mL})$ for $24 \mathrm{~h}$ showed a 1.12 fold decrease compared to negative control and the decrease was statistically significant $(\mathrm{p}<0.05)$. Milosevic et al. (2017) showed that the responses of the cells to various types of SIM derivatives were different. According to their results, one of the newly synthesized SIM derivatives was cytotoxic toward normal fetal lung cells $(62.13 \mu \mathrm{M})$, while the others weren't toxic [37]. On the other hand, Chen et al. (2017) studied the cytotoxicity of mesoporous silica nanoparticles, which were separately conjugated with some cross-linkers containing succinimide groups $(\mathrm{N}-[\alpha$-maleimidoacetoxy]succinimide ester, m-maleimidobenzoyl-Nhydroxysuccinimideester, succinimidyl 4-(N-maleimidomethyl)cyclohexane-1-carboxylate, and maleimide poly(ethylene glycol) succinimidyl carboxymethyl ester). The researchers used the WST-1 assay in macrophages treated with four different amounts $(50,100,250$, and 500 $\mu \mathrm{g} / \mathrm{mL}$ ) of cross-linked nanoparticles to determine the cell viability for the range of 4-24 $\mathrm{h}$ and it was reported that any significant cell death in the treatment of SIM containing linkers was existed [38]. In another study, a novel multifunctional nanosystem formed by magnetite nanoparticles coated with $\mathrm{pH}$-responsive poly(aspartic acid) hydrogel was developed using polysuccinimide for the surface modification of nanoparticle and no cytotoxicity was observed with their materials on mouse fibroblast cells [39].

\section{Hemocompatibility Assay}

A material is defined as highly hemocompatible if the hemolysis $\%$ is less than $5 \%$; hemocompatible if it is in the range of 5 to $10 \%$ and non-hemocompatible if it is higher than $20 \%$ [40]. The hemolysis \% values of the nanoclay samples were listed in Table 3 . Hemolysis $\%$ values were below $5 \%$ for all of the amounts of $\mathrm{K}_{0}, \mathrm{KD}, \mathrm{KD}-\mathrm{GA}$, and $\mathrm{KD}-\mathrm{SIM}$ samples. Moreover, hemolysis \% values of $\mathrm{KD}-\mathrm{CPC}$ and $\mathrm{KD}^{-\mathrm{HDTMA}^{+}}$were below $5 \%$ for the amounts lower than 125 and $500 \mu \mathrm{g} / \mathrm{mL}$, respectively. On the other hand, KD-CPC at the amounts of 125,250 , and $500 \mu \mathrm{g} / \mathrm{mL}$ and KD-HDTMA ${ }^{+}$at the amounts of $500 \mu \mathrm{g} / \mathrm{mL}$ showed hemolysis \% in the range of 5 to $10 \%$. All the results showed that unmodified, DMSO modified, GA modified and SIM intercalated kaolinite nanoclays could be classified as highly hemocompatible for all of the amounts used in this study, while CPC and HDTMA ${ }^{+}$ intercalated kaolinite nanoclays were hemocompatible for the amounts below 125 and 500 $\mu \mathrm{g} / \mathrm{mL}$, respectively. The hemolysis $\%$ values were only statistically significant $(\mathrm{p}<0.05)$ with 
a)

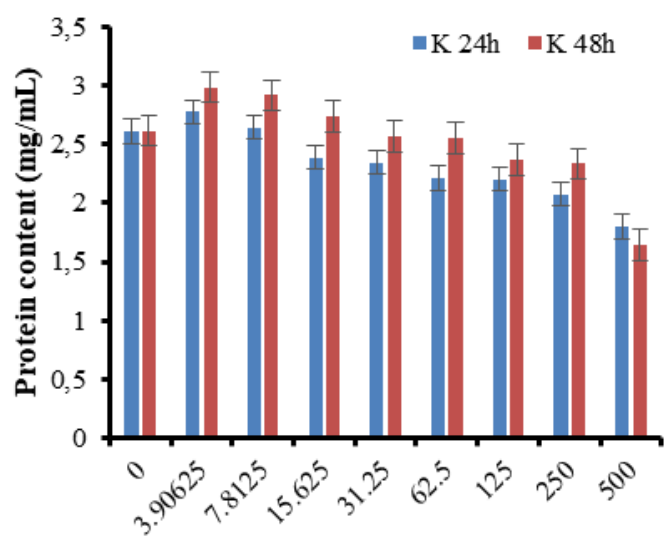

Clay amount $(\mu \mathrm{g} / \mathrm{mL})$

c)

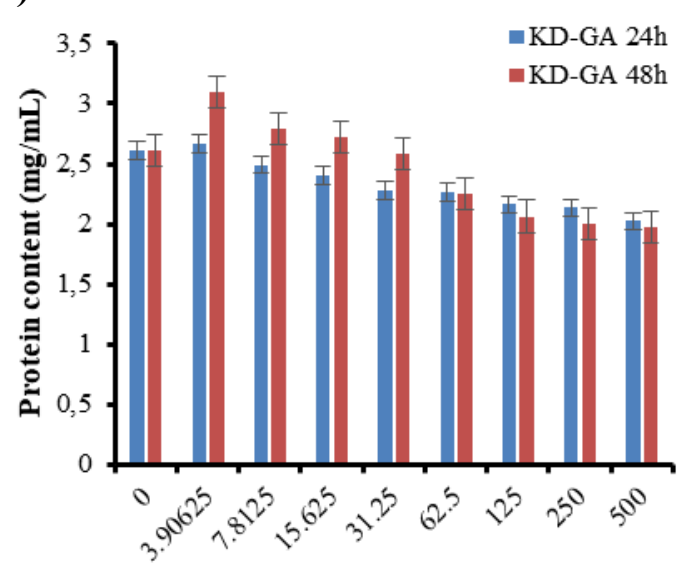

Clay amount $(\mu \mathrm{g} / \mathrm{mL})$

e)

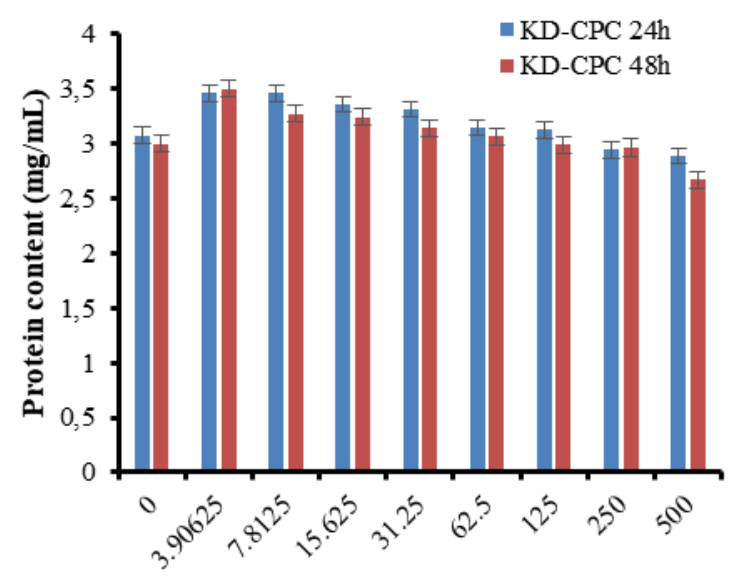

Clay amount $(\mu \mathrm{g} / \mathrm{mL})$ b)

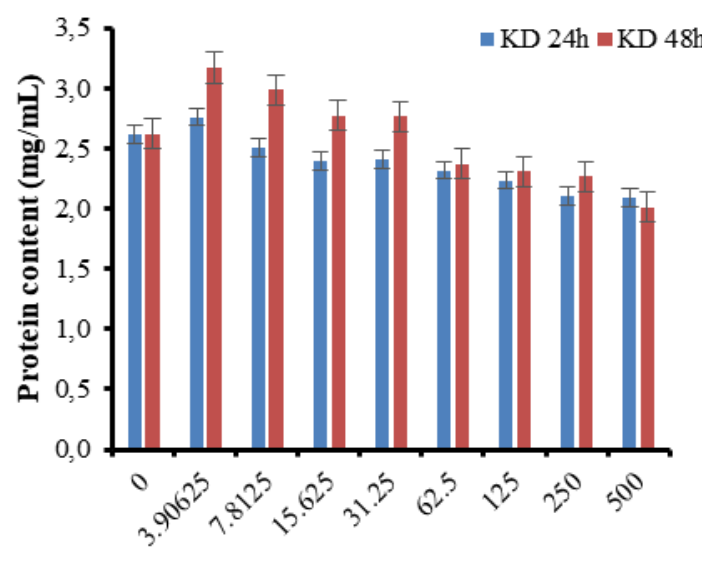

Clay amount $(\mu \mathrm{g} / \mathrm{mL})$

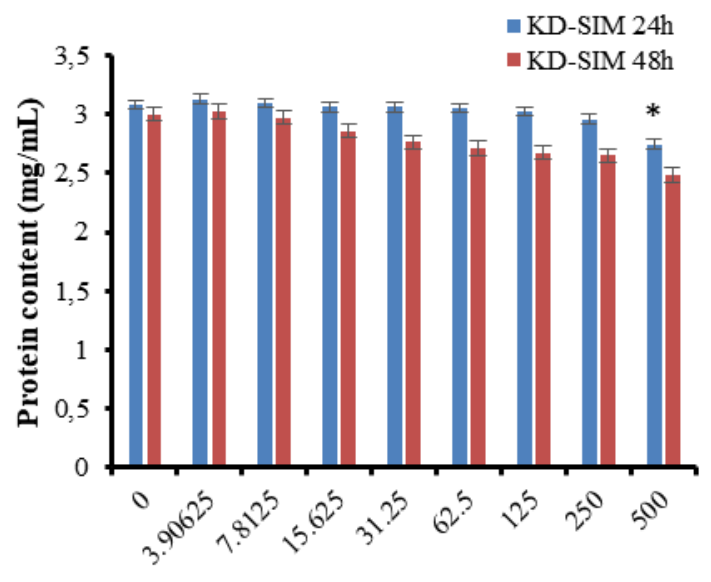

d)

Clay amount $(\mu \mathrm{g} / \mathrm{mL})$

f)

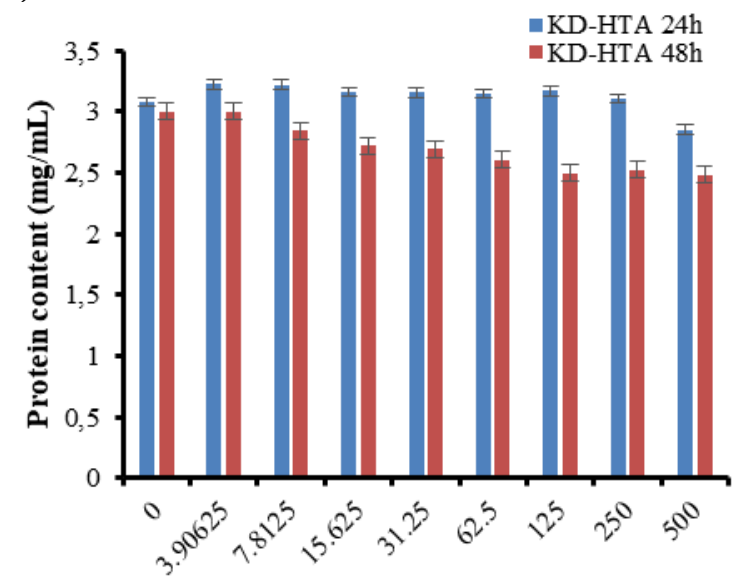

Clay amount $(\mu \mathrm{g} / \mathrm{mL})$

Fig. 7. Bradford assay results of the human lymphocytes treated with different amounts of KO (a); KD (b); KD-GA (c); KD-SIM (d); KD-CPC (e) and KD-HDTMA+ (f). Significance $(p<0.05)$ compared to negative control shown as * 
$\mathrm{KD}-\mathrm{GA}$ at $500 \mu \mathrm{g} / \mathrm{mL}(1.46 \pm 0.05), \mathrm{KD}-\mathrm{CPC}$ at the amounts of $15.62,31.25$, and 500 $\mu \mathrm{g} / \mathrm{mL}\left(1.28 \pm 0.04,3.03 \pm 0.04\right.$, and $10.30 \pm 0.27$, respectively), and $\mathrm{KD}^{-\mathrm{HDTMA}^{+}}$at 250 $\mu \mathrm{g} / \mathrm{mL}(3.31 \pm 0.08)$. In literature no study has been existed recently comparing the hemocompatibilities of the intercalated kaolinite samples, except Liu et al. (2015) [41] who studied the hemocompatibility of halloysite nanotubes which are known as chemically similar to kaolinite [31]. The researchers investigated halloysite nanotubes with anticoagulated rabbit blood to detect its blood compatibility and found that the hemolysis ratios were below $0.5 \%$ and classified them as nonhemolysis samples [41].

Table 3. Hemolysis \% of the samples treated with different amounts of nanoclays (Mean \pm SE). Significance $(p<0.05)$ compared to negative control shown as *.

\begin{tabular}{|c|c|c|c|c|c|c|}
\hline \multicolumn{2}{|c|}{$\mathrm{K}_{0}$} & \multirow{2}{*}{$\begin{array}{l}\mathrm{KD} \\
0.17 \pm 0.194\end{array}$} & KD-GA & D-SIM & KD-CPC & \multirow{2}{*}{$\begin{array}{l}\begin{array}{l}\text { KD- } \\
\text { HDTMA }\end{array} \\
0.28 \pm 0.024\end{array}$} \\
\hline $3.91 \mu \mathrm{g} / \mathrm{mL}$ & $1.21 \pm 0.096$ & & $0.36 \pm 0.014$ & $0.01 \pm 0.013$ & $0.59 \pm 0.140$ & \\
\hline $7.81 \mu \mathrm{g} / \mathrm{mL}$ & $0.40 \pm 0.146$ & $0.23 \pm 0.158$ & $0.01 \pm 0.001$ & $0.05 \pm 0.001$ & $0.34 \pm 0.040$ & $0.84 \pm 0.238$ \\
\hline $15.62 \mu \mathrm{g} / \mathrm{mL}$ & $0.60 \pm 0.277$ & $0.39 \pm 0.145$ & $0.01 \pm 0.035$ & $0.20 \pm 0.123$ & $1.28 \pm 0.04 *$ & $0.54 \pm 0.082$ \\
\hline $31.25 \mu \mathrm{g} / \mathrm{mL}$ & $0.48 \pm 0.061$ & $0.04 \pm 0.004$ & $0.51 \pm 0.111$ & $0.24 \pm 0.136$ & $3.03 \pm 0.04^{*}$ & $0.76 \pm 0.043$ \\
\hline $62.5 \mu \mathrm{g} / \mathrm{mL}$ & $0.34 \pm 0.095$ & $0.65 \pm 0.039$ & $0.39 \pm 0.161$ & $0.21 \pm 0.034$ & $4.27 \pm 0.195$ & $2.43 \pm 0.104$ \\
\hline $125 \mu \mathrm{g} / \mathrm{mL}$ & $0.69 \pm 0.185$ & $0.28 \pm 0.151$ & $0.45 \pm 0.058$ & $0.30 \pm 0.059$ & $6.18 \pm 0.236$ & $2.93 \pm 0.189$ \\
\hline $250 \mu \mathrm{g} / \mathrm{mL}$ & $1.36 \pm 0.178$ & $1.19 \pm 0.261$ & $0.95 \pm 0.188$ & $0.78 \pm 0.113$ & $9.69 \pm 0.523$ & $3.31 \pm 0.08^{*}$ \\
\hline $500 \mu \mathrm{g} / \mathrm{mL}$ & $2.93 \pm 0.254$ & $2.92 \pm 0.269$ & $1.46 \pm 0.05^{*}$ & $1.32 \pm 0.093$ & $10.30 \pm 0.27^{*}$ & $7.30 \pm 0.293$ \\
\hline
\end{tabular}

\section{CONCLUSIONS}

In this work, the intercalation of the kaolinite nanoclays with DMSO, GA, SIM, CPC, and $\mathrm{HDTMA}^{+}$was investigated using different techniques such as XRD, FTIR-ATR, BET, SEM and TEM; and biological properties of synthesized kaolinite samples were determined. Unmodified kaolinite nanoclay wasn't toxic to lymphocytes if the amount was below 125 $\mu \mathrm{g} / \mathrm{mL}$. Kaolinite nanoclay intercalated with DMSO didn't show significant change in cell viability until its maximum amount $(500 \mu \mathrm{g} / \mathrm{mL})$. Among all of the modifications, GA was the best for the kaolinite samples intercalated with DMSO. Because, the viabilities didn't decrease significantly with GA modified kaolinite nanoclays for $24 \mathrm{~h}$ but only decreased at $500 \mu \mathrm{g} / \mathrm{mL}$ for $48 \mathrm{~h}$. The intercalation of kaolinite nanoclay with SIM, CPC, and HDTMA ${ }^{+}$ caused important decreases in lymphocyte viabilities. No significant decrease was observed in protein content of the lymphocyte cells exposed to the kaolinite samples except the one modified with SIM. The protein content of the cells incubated with maximum amount of SIM intercalated kaolinite-DMSO sample for $24 \mathrm{~h}$ showed significant decrease in protein content compared to negative control $(\mathrm{p}<0.05)$ but no significant decrease was observed after $48 \mathrm{~h}$. The unmodified kaolinite nanoclay and the intercalated nanoclays with DMSO, GA, and SIM were highly hemocompatible for all of the amounts used in this study, while CPC and $\mathrm{HDTMA}^{+}$modified kaolinite nanoclays were hemocompatible for the amounts below 125 and 
$500 \mu \mathrm{g} / \mathrm{mL}$, respectively. More research is needed in the future for the evaluation of the toxicological profile of the intercalated nanoclays due to their different reactions.

\section{ACKNOWLEDGMENTS}

We thank the Scientific and Technological Research Council of Turkey (TUBITAK) for the scholarship provided to Begumhan Yilmaz.

\section{REFERENCES}

1. Nazir, M.S., Mohamad-Kassim, M.H., Mohapatra, L., Gilani, M.A., Raza, M.R., Majeed, K. (2016) Secondary characteristic properties of nanoclays and characterization of nanoparticulates and nanocomposites. In: (Jawaid, M., Qaiss, A.e.K., Bouhfid, R.) Nanoclay reinforced polymer composites, Springer Singapore, 35-55.

2. Maisanaba, S., Pichardo, S., Puerto, M., Gutiérrez-Praena, D., Cameán, A., Jos, A. (2015) Toxicological evaluation of clay minerals and derived nanocomposites: A review. Environmental Research, 138, 233-254.

3. Koosha, M., Mirzadeh, H., Shokrgozar, M.A., Farokhi, M. (2015) Nanoclay-reinforced electrospun chitosan/PVA nanocomposite nanofibers for biomedical applications. RSC Advances, 5, 10479-10487.

4. Awada, M, López-Galindo, A., Setti, M., El-Rahmany, M., Iborra C.V. (2017) Kaolinite in pharmaceutics and biomedicine. International Journal of Pharmaceutics, 533, 34-48.

5. Hun-Kim, M., Choi, G., Elzatahry, A., Vinu, A., Bin Choy, Y., Choy, J.-H. (2016) Review of clay-drug hybrid materials for biomedical applications: Administration routes. Clays and Clay Minerals,64, 115-130.

6. Karaog lu, M.H., Dog an, M., Alkan, M. (2010) Removal of reactive blue 221 by kaolinite from aqueous solutions. Industrial \& Engineering Chemistry Research,49, 1534-1540.

7. Ganguly, S., Dana, K., Mukhopadhyay, T.K., Parya, T.K., Ghatak, S. (2011) Organophilic nano clay: A comprehensive review. Transactions of the Indian Ceramic Society,70, 189-206.

8. Zhang, S., Liu, Q., Cheng, H., Zeng, F. (2015) Combined experimental and theoretical investigation of interactions between kaolinite inner surface and intercalated dimethyl sulfoxide. Applied Surface Science,331, 234-240.

9. Benlikaya, R., Bütün, V., Alkan, M. (2016) Modified kaolinites-polyalkyl methacrylate nanocomposites: Exploring relations between solubility parameters and thermal properties for in situ solution polymerization. Polymer Composites,37, 2333-2341.

10. Lordan, S., Kennedy, J.E., Higginbotham, C.L. (2011) Cytotoxic effects induced by unmodified and organically modified nanoclays in the human hepatic HepG2 cell line. Journal of Applied Toxicology,31, 27-35.

11. Maisanaba, S., Pichardo, S., Puerto, M., Gutiérrez-Praena, D., Cameán, A. M., Jos, A. (2015) Toxicological evaluation of clay minerals and derived nanocomposites: A review. Environmental Research,138, 233-254.

12. Rajiv, S., Jerobin, J., Saranya, V., Nainawat, M., Sharma, A., Makwana, P., Gayathri, C., Bharath, L., Singh, M., Kumar, M., Mukherjee, A., Chandrasekaran, N. (2015) Comparative cytotoxicity and genotoxicity of cobalt (II, III) oxide, iron (III) oxide, silicon dioxide, and 
aluminum oxide nanoparticles on human lymphocytes in vitro. Human and Experimental Toxicology, 35, 170-183.

13. Assadian, E., Zarei M., Gilani, A., Mehrzad, F., Farshin, Degampanah, H., Pourahmad, J. (2018) Toxicity of Copper Oxide $(\mathrm{CuO})$ Nanoparticles on Human Blood Lymphocytes. Biological Trace Element Research,184, 350-357.

14. Turhan, Y., Dogan, M., Alkan, M. (2010) Poly (vinyl chloride)/ kaolinite nanocomposites: Characterization and thermal and optical properties. Industrial \& Engineering Chemistry Research,49, 1503-1513.

15. Ota, Y., Ishihara, S., Otani, K., Yasuda, K., Nishikawa, T., Tanaka, T., Tanaka, J., Kiyomatsu, T., Kawai, K., Hata, K., Nozawa, H., Kazama, S., Yamaguchi, H., Sunami, E., Kitayama, J., Watanabe, T. (2016) Effect of nutrient starvation on proliferation and cytokine secretion of peripheral blood lymphocytes. Molecular Clinical Oncology,4, 607-610.

16. Yilmaz, B., Dogan, S., Celikler Kasimogullari, S. (2018) Hemocompatibility, cytotoxicity, and genotoxicity of poly(methylmethacrylate)/nanohydroxyapatite nanocomposites synthesized by melt blending method. International Journal of Polymeric Materials and Polymeric Biomaterials, 67, 1-10.

17. Maisanaba, S., Gutiérrez-Praena, D., Pichardo, S., Moreno, F. J., Jordá, M., Cameán, A. M., Aucejo, S., Jos, Á. (2014) Toxic effects of a modified montmorillonite clay on the human intestinal cell line Caco-2. Journal of Applied Toxicology,34, 714-725.

18. Promega, Celltiter $96^{\circledR}$ aqueous one solution cell proliferation assay, http://Www.Promega.Com/Protocols/, Promega Corporation, Madison, WI 53711 USA, 2012.

19. Ahamed, M., Akhtar, M., Alhadlaq, H., Khan, M., Alrokayan, S. (2015) Comparative cytotoxic response of nickel ferrite nanoparticles in human liver HepG2 and breast MFC-7 cancer cells. Chemosphere, 135, 278-288.

20. Attik, G., Villat, C., Hallay, F., Pradelle Plasse, N., Bonnet, H., Moreau, K., Colon, P., Grosgogeat, B. (2014) In vitro biocompatibility of a dentine substitute cement on human MG63 osteoblasts cells: Biodentine ${ }^{\mathrm{TM}}$ versus MTA ${ }^{\circledR}$. International Endodontic Journal,47, 1133-1141.

21. Motlagh, D., Allen, J., Hoshi, R., Yang, J., Lui, K., \& Ameer, G. (2007). Hemocompatibility evaluation of poly(diol citrate) in vitro for vascular tissue engineering. J Biomed Mater Res A, 82(4), 907-916. doi:10.1002/jbm.a.31211

22. Zhang, S., Liu, Q., Cheng, H., Gao, F., Liu, C., Teppen, B. J. (2018) Mechanism responsible for intercalation of dimethyl sulfoxide in kaolinite: Molecular dynamics simulations. Applied Clay Science, 151, 46-53.

23. Mehdi, K., Bendenia, S., Lecomte-Nana, G. L., Batonneau-Gener, I., Rossignol, F., MaroufKhelifa, K., Khelifa, A. (2018) A new approach about the intercalation of hexadecyltrimethylammonium into halloysite: preparation, characterization, and mechanism. Chemical Papers, 73, 131-139.

24. Elbokl, T.A., Detellier, C. (2008). Intercalation of cyclic imides in kaolinite. Journal of Colloid and Interface Science. 323, 338-348.

25. Lakshmi, M.S., Narmadha, B., Reddy, B.S.R. (2008) Enhanced thermal stability and structural characteristics of different MMT-Clay/epoxy-nanocomposite materials. Polymer Degradation and Stability,93, 201-213.

26. Bowman, P.D., Wang, X., Meledeo, M.A., Dubick, M.A., Kheirabadi, B.S. (2011) Toxicity of aluminum silicates used in hemostatic dressings toward human umbilical veins endothelial cells, HeLa cells, and RAW267.4 mouse macrophages. Journal of Trauma,71, 727-732.

27. Imerys. Kaolin China Clay, 2012. Available from: http://www.imerysperfmins.com/kaolin/eu/kaolin.htm 
28. Michel, C., Herzog, S., de Capitani, C., Burkhardt-Holm, P., Pietsch, C. (2014) Natural mineral particles are cytotoxic to rainbow trout gill epithelial cells in vitro. PLoS One,9 e100856.

29. Murphy, E.J., Roberts, E., Horrocks, L.A. (1993) Aluminum silicate toxicity in cell cultures. Neuroscience,55, 597-605.

30. Bessa, M.J., Costa, C., Reinosa, J., Pereira, C., Fraga, S., Fernández, J., Bañares, M.A., Teixeira, J.P. (2017) Moving into advanced nanomaterials. Toxicity of rutile $\mathrm{TiO}_{2}$ nanoparticles immobilized in nanokaolin nanocomposites on HepG2 cell line. Toxicology and Applied Pharmacology,316, 114-122.

31. Rawtani, D., Agrawal, Y.K. (2012) Multifarious applications of halloysite nanotubes: A review. Reviews on Advanced Materials Science,30, 282-295.

32. Ahmed, F. R., Shoaib, M.H., Azhar, M., Um, S.H., Yousuf, R.I., Hashmi, S., Dar, A. (2015) Invitro assessment of cytotoxicity of halloysite nanotubes against HepG2, HCT116 and human peripheral blood lymphocytes. Colloids Surf B Biointerfaces, 135, 50-55.

33. Mousa, M., Evans, N. D., Oreffo, R. O. C, Dawson, J. I. (2018) Clay nanoparticles for regenerative medicine and biomaterial design: a review of clay bioactivity. Biomaterials, 159 , 204-214.

34. Geh, S., Yücel, R., Duffin, R., Albrecht, C., Borm, P. J.A., Armbruster, L., Raulf-Heimsoth, M., Brüning, T., Hoffmann, E., Rettenmeier, A.W., Dopp, E. (2005) Cellular uptake and cytotoxic potential of respirable bentonite particles with different quartz contents and chemical modifications in human lung fibroblasts. Archives of Toxicology,80, 98-106.

35. Tiburu, E.K., Fleischer, H.N., Aidoo, E.O., Salifu, A., Asimeng, B.O., Zhou, H. (2016) Crystallization of linde type a nanomaterials at two temperatures exhibit differential inhibition of hela cervical cancer cells in vitro. Journal of Biomimetics, Biomaterials and Biomedical Engineering, 28, 66-77.

36. Maisanaba, S., Ortuño, N., Jordá-Beneyto, M., Aucejo, S., Jos, Á. (2017) Development, characterization and cytotoxicity of novel silane-modified clay minerals and nanocomposites intended for food packaging. Applied Clay Science,138, 40-47.

37. Milosevic, N.P., Kojic, V., Curcic, J., Jakimov, D., Milic, N., Banjac, N., Uscumlic, G., Kaliszan, R. (2017) Evaluation of in silico pharmacokinetic properties and in vitro cytotoxic activity of selected newly synthesized n-succinimide derivatives. Journal of Pharmaceutical and Biomedical Analysis, 137, 252-257.

38. Chen, Y.P., Wu, S.H., Chen, I.C., Chen, C.T. (2017) Impacts of cross-linkers on biological effects of mesoporous silica nanoparticles. ACS Applied Materials and Interfaces,9,10254-10265.

39. Vega-Chacón, J., Arbeláez, M.I.A., Jorge, H.J., Marques, R.F.C., Jafelicci Jr, M. (2017) pHresponsive poly(aspartic acid) hydrogel-coatedmagnetite nanoparticles for biomedical applications. Materials Science and Engineering C,77, 366-373.

40. Shanthini, G.M., Martin, C.A., Sakthivel, N., Veerla, S.C., Elayaraja, K., Lakshmi, B. S., Asokan, K., Kanjilal, D., Kalkura, S. N. (2015) Physical and biological properties of the ion beam irradiated PMMA-based composite films. Applied Surface Science,329, 116-126.

41. Liu, H.-Y., Du, L., Zhao, Y.-T., Tian, W.-Q. (2015) In vitro hemocompatibility and cytotoxicity evaluation of halloysite nanotubes for biomedical application. Journal of Nanomaterials, 2015, $1-9$. 